\title{
ОЦІНКА ЕКСТЕР' ЄРУ КОРІВ УКРАЇНСЬКОЇ ЧОРНО-РЯБОЇ МОЛОЧНОЇ ПОРОДИ СУМСЬКОГО РЕГІОНУ ЗА ВИКОРИСТАННЯ МЕТОДИКИ ЛІНІЙНОЇ КЛАСИФІКАЦІї
}

\author{
Самохіна Євгенія Анатоліївна \\ кандидат сільськогосподарських наук, доцент \\ Сумський національний аграрний університет \\ ORCID: 0000-0002-0983-3047 \\ E-mail: f bt@sau.ua
}

Авраменко Лілія Петрівна
студентка магістратури біолого-технологічного факультету
Сумський національний аграрний університет
ORCID: 0000-0002-6387-1685
E-mail: liliaavramenko1099@gmail.com

Кузьменко Олександр Михайлович студент магістратури біолого-технологічного факультету Сумський національний аграрний університет ORCID: 0000-0002-1372-5081 E-mail: meizu.pro.7.plus.9379992@gmail.com

Чубар Аліна Володимирівна студентка магістратури біолого-технологічного факультету Сумський національний аграрний університет ORCID: 0000-0002-1534-2711 E-mail:chubar589@gmail.com

Проведено дослідження корів-первісток української чорно-рябої молочної породи за екстер'єром у стадах Сумського регіону (АФ "Перше Травня" та "Державному підприємстві дослідного господарства Інституту сільського господарства Північного Сходу НААН України"). Оцінювали тварин за методикою лінійної класифікації на 2-4 місяиях після отелення. За 9-ти бальною системою описували 18 ознак екстер'єру. За 100-бальною оцінювали чотири групи екстер'єрних ознак, які характеризують молочний тип, тулуб, кінцівки та вим'я. Оцінка за групові ознаки, які характеризують молочний тип відповідно становила (82,4 та 81,4 балу), тулуб (83,5 та 82,4 балу), кінцівки (82,6 та 81,7 балу), вим'я (81,9 та 80,7 балу) та загальна оцінка за тип (82,5 та 81,5 балу) з вищими показниками у корів стада АФ "Перше Травня". Оцінка описових ознак корів-первісток показала, що ступінь їхнього розвитку, в порівнянні з груповими, відрізняється істотно вищою мінливістю як в нутрі стада, так і між стадами з коефріцієнтами варіацій 11,9-37,3\%. В обох піддослідних господарствах встановлено достатній для ефрективної селекції рівень зв'язку величини надою із груповими ознаками екстер'єру, які характеризують вираженість молочного типу корів ( $r=0,338$ та 0,279), розвиток тулуба ( $r=0,422$ та 0,344) якість вимені (r=0,315 та 0,299) та загальною оцінкою типу (r=0,328 та 0,277). Позитивний зв'язок з надоєм спостерігався за рядом окремих описових ознак екстер'єру аналогічно у межах підконтрольних господарств: висотою у крижах $(r=0,355$ та 0,266), әлибиною тулуба ( $r=0,326$ та 0,333), кутастістю (r=0,355 та 0,328), шириною заду ( $r=0,398$ та 0,341), поставою тазових кінцівок ( $r=0,402$ та 0,304), переднім ( $r=0,312$ та 0,267) та заднім прикріпленням вимені (r=0,151 та 0,145), центральною зв'язкою ( $r=0,237$ та 0,263), переміщенням ( $r=0,253$ та 0,227). Між вгодованістю та надоєм кореляція від'ємна (r=-0,222 та -0,188). Використання у селекційному процесі молочної худоби методики лінійної класифрікації дозволяє визначити породні особливості екстер'єру тварин, а істотна кореляція між лінійними ознаками та надоєм підтверджує необхідність опосередкованої селекції за типом, що дозволить поліпшити як екстер'єр, так і молочну продуктивність.

Ключові слова: українська чорно-ряба молочна порода, екстер’єр, надій, лінійна оцінка типу, кореляція.

DOI: https://doi.org/10.32845/bsnau.Ivst.2021.1.12

Науковими дослідженнями доведено [1, 2, 5, 7, 10, 11], що використання голштинів при створенні української чорно-рябої молочної породи та її подальшому удосконаленні, достовірно поліпшує тип будови тіла та морфологічні якості вимені. Разом з тим, в процесі схрещування худоби різного походження у якості материнської, за використання всіляких методів підбору, спостерігалося формування різних зональних типів, які у тій чи іншій мірі відрізняються за показниками продуктивності та типу. Сучасний стан селекції чорно-рябої худоби Сумського регіону відрізняється від

попереднього поглинальним схрещуванням помісних генотипів української чорно-рябої молочної породи з голштинськими плідниками зарубіжного походження [12]. Тобто, наразі здійснюється відповідний вплив генофонду голштинської породи на господарськи корисні ознаки тварин взагалі та на показники екстер'єрного типу зокрема. У зв'язку з цією ситуацією нами проведені дослідження з оцінки екстер'єру корів української чорно-рябої молочної породи за використання методики лінійної класифрікації.

Матеріали та методи досліджень. Оцінку корів 
проводили у двох стадах з розведення даної породи: АФ "Перше Травня" та "Державному підприємстві дослідного господарства Інституту сільського господарства Північного Сходу НААН України” (“ДП ДГ ІСГ Північного сходу НААН України"), які розташовані в Сумському районі. Оцінка екстер'єрного типу корів-первісток проводилася за методикою лінійної класифікації [13] у віці 2-4 місяців після отелення за двома системами: 9-бальною, з лінійним описом 18 статей екстер'єру і 100-бальною з урахуванням чотирьох комплексів селекційних ознак, які характеризують: молочний тип, тулуб, кінцівки і вим'я. Кожна група екстер'єрних ознак оцінювалася незалежно маючи свій ваговий коефіцієнт у фінальній оцінці (ФО) тварини: молочний тип (МТ) - $15 \%$, тулуб (Т) $-20 \%$; кінцівки (К) - $25 \%$ та вим'я (В) - $40 \%$.

Загальну оцінку типу визначали за формулою: $30=($ MT 0,15$)+(\mathrm{T} \cdot 0,20)+(\mathrm{K} \cdot 0,25)+(\mathrm{B} \cdot 0,40)$

Дані експериментальних досліджень опрацьовували біометричними методами на ПК у середовищі Microsoft Office Excel за використання програмного забезпечення за формулами, наведеними Е. К. Меркурьевой [3].

Достовірність величин оцінювали через критерії Стьюдента за першого (1 $\mathrm{P}<0,05)$, другого (2 $\mathrm{P}<0,01)$ i третього ( $\left.{ }^{3} \mathrm{P}<0,001\right)$ порогів достовірності.

Результати досліджень з оцінки корів-первісток підконтрольних господарств свідчать, що ступінь розвитку групових та основних описових лінійних ознак екстер'єру відрізняються певною внутрі- та міжстадною мінливістю (табл. 1).
Показники оцінки групових ознак екстер'єру тварин стада АФ "Перше Травня" показують, що корови-первістки даного господарства мають істотну перевагу над ровесницями підприємства "ДП ДГ ІСГ Північного сходу НААН України", з достовірною різницею на 1,0 бал за молочним типом, на 1,1 балу - за розвитком тулуба, на 0,9 балу, за станом кінцівок і на 1,2 балу - за морфологічними ознаками вимені. Достовірна різниця на користь корів-первісток АФ "Перше Травня" за фінальною оцінкою типу склала 1,0 бал.

Чітке уявлення про розвиток найважливіших статей екстер'єру корови відокремлено від групових, які мають економічну (функціональну, селекційну) цінність, дає описова система лінійної оцінки.

За цією системою обов'язково описуються визначені ICAR [18] ознаки екстер'єру корови, що включені до характеристик групових ознак молочного типу, тулуба, кінцівок та вимені з урахуванням певного переліку недоліків, які найчастіше зустрічаються у тварин. При оцінці тварин за єдиною 9-бальною шкалою середня вираженість ознаки оцінюється у п'ять балів, а біологічні відхилення у бік погіршення розвитку із зменшенням балів до одного і, навпаки, якщо розвиток ознаки зростає, оцінка збільшується до дев'яти балів. Згідно з параметрами лінійних ознак молочної худоби, максимальна оцінка у 9 балів не завжди характеризує бажаний тип розвитку статі екстер'єру. Це стосується таких ознак, як положення заду, кут скакального суглоба, глибина вимені, розміщення та довжина дійок.

Таблиця 1

Показники лінійної оцінки корів-первісток української чорно-рябої молочної породи, (балів)

\begin{tabular}{|c|c|c|c|c|}
\hline \multirow{2}{*}{ Ознаки екстер'єру } & \multicolumn{2}{|c|}{ ПЗ "Перше Травня" (n=76) } & \multicolumn{2}{|c|}{ “ДП ДГ ІСГ Північного сходу НААН України”, (n=88) } \\
\hline & $M \pm m$ & $\mathrm{Cv}, \%$ & $M \pm m$ & $\mathrm{CV}, \%$ \\
\hline Комплекс ознак, що характеризує: молочний тип & $82,4 \pm 0,26$ & 2,71 & $81,4 \pm 0,26$ & 3,22 \\
\hline тулуб & $83,5 \pm 0,18$ & 1,92 & $82,4 \pm 0,22$ & 3,18 \\
\hline кінцівки & $82,6 \pm 0,14$ & 1,55 & $81,7 \pm 0,25$ & 2,33 \\
\hline вим'я & $81,9 \pm 0,26$ & 2,73 & $80,7 \pm 0,26$ & 3,14 \\
\hline Загальна оцінка & $82,5 \pm 0,17$ & 1,84 & $81,5 \pm 0,27$ & 2,61 \\
\hline Висота в крижах & $5,7 \pm 0,14$ & 21,1 & $5,4 \pm 0,15$ & 24,9 \\
\hline Ширина грудей & $5,9 \pm 0,19$ & 28,7 & $6,2 \pm 0,17$ & 23,3 \\
\hline Глибина тулуба & $7,8 \pm 0,11$ & 11,9 & $7,6 \pm 0,14$ & 21,3 \\
\hline Кутастість & $6,9 \pm 0,15$ & 19,4 & $6,2 \pm 0,18$ & 23,4 \\
\hline Нахил заду & $4,8 \pm 0,15$ & 26,8 & $5,5 \pm 0,16$ & 25,3 \\
\hline Ширина заду & $5,4 \pm 0,17$ & 27,4 & $5,2 \pm 0,14$ & 23,6 \\
\hline Кут скакального суглоба & $4,7 \pm 0,12$ & 23,3 & $5,6 \pm 0,11$ & 21,5 \\
\hline Постава тазових кінцівок & $5,8 \pm 0,16$ & 23,7 & $6,0 \pm 0,14$ & 21,6 \\
\hline Кут ратиць & $4,5 \pm 0,11$ & 21,8 & $5,5 \pm 0,12$ & 22,8 \\
\hline Переднє прикріплення вимені & $7,0 \pm 0,14$ & 17,8 & $6,1 \pm 0,17$ & 22,9 \\
\hline Заднє прикріплення вимені & $4,6 \pm 0,17$ & 31,1 & $4,2 \pm 0,15$ & 28,6 \\
\hline Центральна зв'язка & $5,4 \pm 0,19$ & 30,7 & $5,2 \pm 0,23$ & 37,3 \\
\hline Глибина вимені & $6,6 \pm 0,15$ & 20,2 & $5,5 \pm 0,19$ & 23,4 \\
\hline Розміщення передніх дійок & $4,7 \pm 0,13$ & 23,9 & $4,6 \pm 0,15$ & 35,2 \\
\hline Розміщення задніх дійок & $6,4 \pm 0,12$ & 16,4 & $4,8 \pm 0,14$ & 21,8 \\
\hline Довжина дійок & $5,2 \pm 0,12$ & 20,4 & $5,5 \pm 0,11$ & 18,6 \\
\hline Переміщення (хода) & $5,8 \pm 0,09$ & 13,0 & $5,6 \pm 0,12$ & 15,5 \\
\hline Вгодованість & $5,7 \pm 0,17$ & 26,3 & $6,5 \pm 0,14$ & 26,6 \\
\hline
\end{tabular}

Порівняльний аналіз засвідчив кращий розвиток ознаки висоти в крижах первісток стада ПЗ “Перше Травня". Проте більш широкогрудими виявилися тварини "ДП ДГ ІСГ Північного сходу НААН України", що свідчить про наявність у даному стаді корів з відхиленням до комбінованого типу. За розвитком глибини грудей корови-первістки обох стад перевищують середній рівень даного показника. Молочний хара- ктер тварин відображає кутастість, оцінка за яку 6,9 балу свідчить про краще виражений молочний тип у первісток господарства "Перше Травня" у порівнянні з ровесницями "ДП ДГ ІСГ Північного сходу НААН України", у яких оцінка становила 6,2 балу, різниця 0,7 балу достовірна при $\mathrm{P}<0,01$. За нахилом крижів у тварин обох стад спостерігалися недоліки, з дещо вираженим ступенем піднятості у первісток АФ

Вісник Сумського національного аграрного університету 
"Перше Травня" (4,8 балу) та з більш вираженим нахилом (5,5 балу) у ровесниць "ДП ДГ ІСГ Північного сходу НААН України". За ознакою ширини заду тварини обох господарств мають подібний розвиток з оцінкою 5,4 і 5,2 балу, що дещо краще середнього показника у породі.

Середня оцінка кута скакального суглоба на рівні 5,6 балу у корів-первісток "ДП ДГ ІСГ Північного сходу НААН України" свідчить про те, що серед оціненого поголів'я зустрічаються тварини з недоліком статі - шаблистістю. Дана ознака має кращий розвиток (4,8 балу) у тварин АФ "Перше Травня", хоча серед них також, але рідше, зустрічаються корови з недоліком статі - слоновістю.

За поставою задніх кінцівок оцінені тварини обох господарств майже не відрізняються. Оцінка за кут ратиць відповідно 4,5 у корів АФ “Перше Травня" свідчить про існуючу проблему у тварин - крихкість ратичного рогу, яку необхідно вирішувати відповідним підбором бугаїв-плідників з високими показниками лінійної оцінки їхніх дочок за цією ознакою. Оцінка за кут ратиць відповідно 5,5 балу у ровесниць "ДП ДГ ІСГ Північного сходу НААН України", що достовірно вище на 1 бал $(\mathrm{P}<0,001)$, свідчить про кращий розвиток ознаки. кращим розвитком відрізнялися корови-первістки стада АФ "Перше Травня" з середньою оцінкою 7,0 балів з високодостовірною різницею на свою користь 0,9 балу $(\mathrm{P}<0,001)$. Прикріплення задніх часток вимені було також кращим у тварин стада АФ "Перше Травня" (4,6 балу), хоча нижчим за середній рівень.

Ознака центральної зв'язки у тварин обох господарств має середній рівень розвитку 5,4 і 5,2 балу і також свідчить про необхідність їі поліпшення шляхом раціонального підбору бугаїв-плідників. Оцінка за глибину вимені на середньому рівні 6,6 і 5,5 балів відповідно у оцінюваних стадах з кращим показником у первісток АФ “Перше Травня", що достовірно
За ознакою прикріплення передніх часток вимені

вище на 1,1 бал $(P<0,001)$ у порівнянні з ровесницями "ДП ДГ ІСГ Північного сходу НААН України".

При визначенні ознаки переміщення корів у процесі руху встановлено, що у оцінюваних тварини спрямування ходи та лінійне пересування у просторі знаходиться на задовільному рівні, про що свідчать середні показники оцінки 5,8 та 5,6 балу відповідно.

Досить високі показники варіації переважної більшості описових ознак свідчать, якою мірою підконтрольні стада не достатньо консолідовані за тією чи іншою ознакою екстер'єру. Найвищі коефіцієнти варіації сягнули 37,3\% (центральна зв'язка) і 35,2\% (розміщення передніх дійок) у тварин стада "ДП ДГ ІСГ Північного сходу НААН України". Досить високі показники мінливості багатьох інших ознак свідчать про необхідність впровадження лінійної класифікації з метою ретельної оцінки бугаїв-плідників.

Запровадження методики лінійної класифікації зумовило численні дослідження з визначення зв'язків окремих лінійних та групових ознак з основними господарськи корисними показниками. Найбільш дослідженим $€$ зв'язок екстер'єру з молочною продуктивністю, вмотивованість вивчення та існування якого закладена у самій ідеї методології лінійної класифікації тварин молочної худоби. Наведена в літературних джерелах висока мінливість кореляцій за описовими та груповими лінійними ознаками екстер'єру корів [4, $6,8,9,14,16,17,19,20]$ свідчить про необхідність ретельного вивчення цього питання, оскільки наявність низької або від'ємної співвідносної мінливості ускладнює ефективність одночасної селекції за продуктивністю та екстер'єрним типом.

Отже, одним із головних факторів успішної селекції в популяції молочної худоби є рівень кореляційної мінливості, у тому числі й лінійних ознак екстер'єру зв'язаних з молочною продуктивністю, табл. 2.

Таблиця 2

\section{Зв'язок лінійної оцінки корів-первісток української чорно-рябої молочної породи з надоєм за 305 днів лактації}

\begin{tabular}{|c|c|c|c|c|}
\hline \multirow{2}{*}{ Ознаки екстер'єру } & \multicolumn{2}{|c|}{ ПЗ “Перше Травня” (n=76) } & \multicolumn{2}{|c|}{ “ДП ДГ ІСГ Північного сходу НААН України”, (n=90) } \\
\hline & $r \pm m_{r}$ & $t_{r}$ & $r \pm m_{r}$ & $\mathrm{tr}_{\mathrm{r}}$ \\
\hline Комплекс ознак, що характеризує: молочний тип & $0,338 \pm 0,078^{3}$ & 4,33 & $0,279 \pm 0,084^{3}$ & 3,38 \\
\hline тулуб & $0,422 \pm 0,073^{3}$ & 5,78 & $0,344 \pm 0,077^{3}$ & 4,07 \\
\hline кінцівки & $0,166 \pm 0,0691$ & 2,41 & $0,144 \pm 0,081$ & 1,33 \\
\hline вим'я & $0,315 \pm 0,070^{3}$ & 4,50 & $0,299 \pm 0,082^{3}$ & 3,38 \\
\hline Загальна оцінка & $0,328 \pm 0,072^{3}$ & 4,56 & $0,277 \pm 0,082^{3}$ & 3,32 \\
\hline Висота в крижах & $0,355 \pm 0,071^{3}$ & 5,00 & $0,266 \pm 0,079^{3}$ & 3,36 \\
\hline Ширина грудей & $0,101 \pm 0,072$ & 1,40 & $0,122 \pm 0,074$ & 1,56 \\
\hline Глибина тулуба & $0,326 \pm 0,068^{3}$ & 4,80 & $0,333 \pm 0,075^{3}$ & 4,12 \\
\hline Кутастість & $0,355 \pm 0,073^{3}$ & 4,86 & $0,328 \pm 0,084^{3}$ & 3,79 \\
\hline Нахил заду & $0,106 \pm 0,075$ & 1,41 & $0,045 \pm 0,072$ & 1,22 \\
\hline Ширина заду & $0,398 \pm 0,079^{3}$ & 5,04 & $0,341 \pm 0,074^{3}$ & 3,44 \\
\hline Кут скакального суглоба & $0,052 \pm 0,072$ & 0,72 & $0,044 \pm 0,073$ & 0,89 \\
\hline Постава тазових кінцівок & $0,402 \pm 0,076^{3}$ & 5,29 & $0,304 \pm 0,079^{3}$ & 4,33 \\
\hline Кут ратиць & $0,120 \pm 0,074$ & 1,62 & $0,094 \pm 0,075$ & 1,22 \\
\hline Переднє прикріплення вимені & $0,312 \pm 0,074^{3}$ & 4,22 & $0,267 \pm 0,074^{3}$ & 3,31 \\
\hline Заднє прикріплення вимені & $0,151 \pm 0,076^{1}$ & 2,13 & $0,145 \pm 0,076^{1}$ & 1,96 \\
\hline Центральна зв'язка & $0,237 \pm 0,072^{3}$ & 3,29 & $0,263 \pm 0,075^{2}$ & 2,61 \\
\hline Глибина вимені & $0,044 \pm 0,075$ & 0,58 & $-0,119 \pm 0,077^{1}$ & 1,98 \\
\hline Розміщення передніх дійок & $-0,144 \pm 0,072^{1}$ & 2,00 & $-0,112 \pm 0,076^{1}$ & 2,01 \\
\hline Розміщення задніх дійок & $-0,124 \pm 0,073$ & 1,70 & $-0,131 \pm 0,0741$ & 2,15 \\
\hline Довжина дійок & $0,204 \pm 0,072^{2}$ & 2,83 & $0,111 \pm 0,071$ & 1,33 \\
\hline Переміщення (хода) & $0,253 \pm 0,075^{3}$ & 3,37 & $0,227 \pm 0,074^{2}$ & 2,86 \\
\hline Вгодованість & $-0,222 \pm 0,073^{2}$ & 3,04 & $-0,188 \pm 0,075^{1}$ & 2,16 \\
\hline
\end{tabular}


Високий рівень достовірного додатного зв'язку з величиною надою виявлено за груповими ознаками екстер'єру, що характеризують вираженість молочного типу корів обох піддослідних господарств АФ "Перше Травня" та "ДП ДГ ІСГ Північного сходу НААН України" відповідно $(\mathrm{r}=0,338$ та 0,$279 ; \mathrm{P}<0,001)$, розвиток тулуба $(\mathrm{r}=0,422$ та 0,344; $P<0,001)$ якість вимені $(r=0,315$ та 0,299; $P<0,001)$ та загальною оцінкою типу ( $r=0,328$ та 0,277; $P<0,001)$.

Позитивний зв'язок з надоєм спостерігався за рядом окремих описових ознак екстер'єру аналогічно у межах підконтрольних господарств: висотою у крижах ( $r=0,355$ та 0,266), глибиною тулуба ( $r=0,326$ та 0,333), кутастістю $(r=0,355$ та 0,328), шириною заду ( $r=0,398$ та 0,341$)$, поставою тазових кінцівок ( $r=0,402$ та 0,304), переднім ( $r=0,312$ та $0,267)$ та заднім прикріпленням вимені $(r=0,151$ та 0,145), центральною зв'язкою ( $r=0,237$ та 0,263), переміщенням ( $r=0,253$ та 0,227). Між вгодованістю та надоєм кореляція від'ємна ( $r=-0,222$ та -0,188). Отримані нами від'ємні коефіці- єнти кореляцій узгоджуються з дослідженнями голштинських корів у різних країнах світу з коефіцієнтами генетичної кореляції між цими ознаками -0,34 [20], -0,20 [19], -0,45 [16] та 0,38 [15].

Висновки. 1. Використання у селекційному процесі молочної худоби доступної методики лінійної класифрікації дозволяє об'єктивно визначити породні особливості екстер'єрного типу тварин.

2. Отримані високі рівні коефріцієнтів мінливості окремих описових статей екстер'єру свідчать про необхідність їхнього поліпшення у частини тварин підконтрольних стад шляхом закріплення бугаїв-поліпшувачів, оцінених за типом їхніх дочок.

3. Встановлена істотна та достовірна кореляція між лінійними ознаками екстер'єру та надоєм за першу лактацію підтверджує необхідність опосередкованої селекції молочної худоби за типом, що дозволить поліпшити як екстер'єр, так і молочну продуктивність.

\section{Список використаної літератури:}

1. Кочук-Ященко О. А. Лінійна оцінка екстер'єру і молочна продуктивність корів-первісток українських чорно-рябої і червоно-рябої молочних порід різних генотипів за часткою спадковості голштинської породи. Аграрна наука, освіта, виробництво: європейський досвід для України: матеріали міжнар. наук.-практ. конф., 17-18 листопада 2015 р. Житомир, 2015. С. 406-409.

2. Кочук-Ященко О. А. Результати лінійної оцінки екстер'єру та молочної продуктивності корів-первісток української червоно-рябої молочної породи різних генотипів. Вісн. Житомирського нац. агроекол. ун-ту. 2015. № 2 (52), т. 3. С. 113-121.

3. Меркурьева Е. К. Генетические основы селекции в скотоводстве. Москва : Колос, 1977. 240 с.

4. Новоселова К. С. Связь молочной продуктивности коров-первотелок с экстерьером в СХПК-СХА (колхоз) "Первое Мая". Актуальные вопросы совершенствования технологии производства и переработки продукции сельского хозяйства. 2019. № 21. C. 356-359.

5. Полупан Ю. П. Оцінка бугаїв за типом дочок. Вісник аграрної науки. 2000. № 5. С. 45-49.

6. Полупан Ю. П. Повторяемость и взаимосвязь инструментальной и глазомерной оценки экстерьера крупного рогатого скота. Сельскохозяйственная биология. 2000. № 2. С. 108-114.

7. Хмельничий Л. М. Особливості екстер'єрного типу корів української чорно-рябої молочної породи Черкаського регіону оцінених за методикою лінійної класифікації. Розведення і генетика тварин. Міжвідомчий тематичний науковий збірник. К. 2017. Вип. 54. С. 112-119.

8. Хмельничий Л. М. Успадковуваність та кореляційна мінливість лінійних ознак екстер'єру корів-первісток української червоно-рябої молочної породи Черкащини. Науково-інформаційний Вісник Херсонського державного аграрного університету. Херсон. 2018. Вип. 11. С. 73-75.

9. Хмельничий Л. М., Вечорка В. В. Вплив лінійних ознак екстер'єру на стан молочної продуктивності корів-первісток українських чорно-рябої та червоно-рябої молочних порід. Вісник Сумського НАУ. Серія «Тваринництво». - 2020. - Вип. 1(40). - C.11-16. DOI: https://doi.org/10.32845/bsnau.lvst.2020.1.2

10. Хмельничий Л. М., Вечорка В. В. Вплив спадкових чинників на екстер'єрний тип корів української чорно-рябої молочної породи. Розведення та селекція тварин: досягнення, проблеми, перспективи: збірник наукових праць міжнар. наук.практ. конф., 20 квітня 2018 р. Житомир: Полісся, 2018. С. 105-110.

11. Хмельничий Л. М., Вечорка В. В., Хмельничий С. Л. Особливості екстер'єрного типу молочної худоби різного походження та співвідносна мінливість лінійних ознак з надоєм корів голштинської породи. Розведення і генетика тварин. 2018. Вип. 56. С.77-83.

12. Хмельничий Л. М., Карпенко Б. М. Екстер'єрний тип корів-первісток голштинської породи оцінених за методикою лінійної класифікації. Розведення і генетика тварин. К. 2020. Вип. 60, С. 78-84. DOI: https://doi.org/10.31073/abg.60.01

13. Хмельничий Л. М., Ладика В. І., Полупан Ю. П., Братушка Р. В., Прийма С. В., Вечорка В. В. Лінійна класифікація корів молочних і молочно-м'ясних порід за типом. (Методичні вказівки) - 2-е вид., перероб. і доп. Суми : Сумський національний аграрний університет, 2016. 27 с.

14. Alphonsus, C., Akpa G.N., Oni O.O., Rekwot P.I., Barje P.P., and Yashim S.M., 2010. Relationship of Linear Conformation Traits with Bodyweight, Body Condition Score and Milk yield in Friesian × Bunaji Cows, Journal of Applied Animal Research, 38(1): 97-100. https://doi.org/10.1080/09712119.2010.9707164

15. Bilal, G., Cue, R. I., and Hayes, J.F. 2016. Genetic and phenotypic associations of type traits and body condition score with dry matter intake, milk yield, and number of breedings in first lactation. Can. J. Anim. Sci. 96:434-447. doi:org/10.1139/cjas2015-0127.

16. De Haas Y,. Janss L. L. G., Kadarmideen H. N. Genetic and phenotypic parameters for conformation and yield traits in three Swiss dairy cattle breeds. J. Anim. Breed. Genet. 2007. 124(1), pp. 12-19. DOI: 10.1111/j.1439-0388.2007.00630.x 
17. Efimova L. V., Rostovtseva N. M., Kulakova T. V., Ivanova O. V., Ivanov E. A. Russian Journal of Agricultural and Biological Sciences., 2017. Vol. 5, No. 2, pp. 4-15.

18. ICAR Guidelines for Conformation Recording of Dairy Cattle, Beef Cattle and Dairy Goats, $1 / 76$. Section -5 , Conformation Recording, version June, 2018. [Електронний ресурс]. - Режим доступу: https://www.icar.org/Guidelines/05-ConformationRecording.pdf

19. Tapki, I. and Ziya G.Y., 2013. Genetic and phenotypic correlations between linear type traits and milk production yields of Turkish Holstein dairy cows. Green. J. Agric. Sci. 3(11): 755-761.

20. Zink, V., L. Zavadilová, J. Lassen, M. Štípková, M. Vacek, L. Štolc. 2014. Analyses of genetic relationships between linear type traits, fat-to-protein ratio, milk production traits, and somatic cell count in first-parity Czech Holstein cows. Czech J. Anim. Sci., 59(12): 539-547.

\section{References:}

1. Kochuk-Yashchenko, O. A., 2015. Liniina otsinka eksterieru i molochna produktyvnist koriv-pervistok ukrainskykh chornoriaboi i chervono-riaboi molochnykh porid riznykh henotypiv za chastkoiu spadkovosti holshtynskoi porody [Linear assessment of the conformation and milk productivity of firstborn cows of Ukrainian Black- and Red-and-White dairy breeds of different genotypes by the share of Holstein heredity]. In: Zhytomyr, Agrarian science, education, production: European experience for Ukraine: Proceedings of the International Conference, Zhytomyr, November, 17-18, pp. 406-409.

2. Kochuk-Yashchenko, O. A., 2015. Rezultaty lininoi otsinky eksterieru ta molochnoi produktyvnosti koriv-pervistok ukrainskoi chervono-riaboi molochnoi porody riznykh henotypiv [Results of linear estimation conformation and milk production of cows firstborn Ukrainian Red-and-White dairy breed of different genotypes]. Visn. Zhytomyrskoho nats. ahroekol. un-tu., no. 2(52), pp. 113-121.

3. Merkur'eva, E. K., 1977. Geneticheskie osnovy selektsii v skotovodstve [Genetic bases of selection in animal husbandry]. Moskva: Kolos.

4. Novoselova, K. S., 2019. Svyaz' molochnoy produktivnosti korov-pervotelok s ekster'erom v SKhPK-SKhA (kolkhoz) "Pervoe Maya" [Relationship of firstborn cows milk productivity with the conformation in the APC-AA (collective) "Pervoe Maya"]. Aktual'nye voprosy sovershenstvovaniya tekhnologii proizvodstva i pererabotki produktsii sel'skogo khozyaystva, no. 21, pp. 356359.

5. Polupan, Yu. P., 2000. Otsinka buhaiv za typom dochok [Estimation of sires according to the type of daughters]. Visnyk ahrarnoi nauky, issue 5, pp. 45-49.

6. Polupan, Yu. P., 2000. Povtoryaemost' i vzaimosvyaz' instrumental'noy i glazomernoy otsenki ekster'era krupnogo rogatogo skota [Repeatability and interrelation of the instrumental and visual assessment of the cattle conformation]. Sel'skokhozyaystvennaya biologiya, no. 2, pp. 108-114.

7. Khmelnychyi, L. M., 2017. Osoblyvosti eksteriernoho typu koriv ukrainskoi chorno-riaboi molochnoi porody Cherkaskoho rehionu otsinenykh za metodykoiu lininoi klasyfikatsii [Conformation type features of cows Ukrainian Black-and-White dairy breed in Cherkassy region estimated by the method of linear classification]. Rozvedennia i henetyka tvaryn, issue 54, pp. 112-119.

8. Khmelnychyi, L. M., 2018. Uspadkovuvanist ta koreliatsiina minlyvist liniinykh oznak eksterieru koriv-pervistok ukrainskoi chervono-riaboi molochnoi porody Cherkashchyny [Heritability and correlation variability of linear conformation traits cows firstborn Ukrainian Red-and-White dairy breed of Cherkasy region]. Naukovo-informatsiinyi Visnyk Khersonskoho derzhavnoho ahrarnoho universytetu. Kherson, issue 11, pp. 73-75.

9. Khmelnychyi, L. M. and Vechorka, V. V., 2020. Influence of linear conformation traits on the state of milk productivity cows firstborn of Ukrainian Black- and Red-and-White dairy breeds [Vplyv liniinykh oznak eksterieru na stan molochnoi produktyvnosti koriv-pervistok ukrainskykh chorno-riaboi ta chervono-riaboi molochnykh porid]. Visnyk Sumskoho natsionalnoho ahrarnoho universytetu. Seriia «Tvarynnytstvo», issue 1(40), pp. 11-16. doi: https://doi.org/10.32845/bsnau.lvst.2020.1.2

10. Khmelnychyi, L. M. and Vechorka, V. V., 2018. Vplyv spadkovykh chynnykiv na ekster"yernyy typ koriv ukrayins'koyi chorno-ryaboyi molochnoyi porody [Influence of hereditary factors on the conformation type of Ukrainian Black-and-White dairy breed]. In: Zhytomyr: Polissya, Rozvedennya ta selektsiya tvaryn: dosyahnennya, problemy, perspektyvy: zbirnyk naukovykh prats' mizhnar. nauk.-prakt. konf., Proceedings of the International Conference, Zhytomyr, April 20, pp. 105-110.

11. Khmelnychyi, L. M., Vechorka, V. V. and Khmelnychyi, S. L., 2018. Osoblyvosti eksteriernoho typu molochnoi khudoby riznoho pokhodzhennia ta spivvidnosna minlyvist liniinykh oznak z nadoiem koriv holshtynskoi porody [Features of the dairy cattle conformation type of different origin and relative variability of linear traits with milk yield of Holstein cows]. Rozvedennia $i$ henetyka tvaryn. Mizhvidomchyi tematychnyi naukovyi zbirnyk, issue 56, pp. 77-83.

12. Khmelnychyi, L. M. and Karpenko, B. M., 2020. Eksteriernyi typ koriv-pervistok holshtynskoi porody otsinenykh za metodykoiu liniinoi klasyfikatsii [Conformation type firstborn cows of Holstein breed estimated by the method of linear classification]. Rozvedennia i henetyka tvaryn, issue 60, pp. 78-84. DOI: https://doi.org/10.31073/abg.60.01

13. Khmelnychyi, L. M., Ladyka, V. I., Polupan, Yu. P., Bratushka, R. V., Pryima, S. V. and Vechorka, V. V., 2016. Liniina klasyfikatsiia koriv molochnykh i molochno-miasnykh porid za typom. (Metodychni vkazivky) - 2-e vyd., pererob. i dop. [Linear classification of dairy and dairy-meat cows by type. (Methodical instructions). 2nd ed., reworked and ext.]. Sumy: Sumskyi natsionalnyi ahrarnyi universytet.

14. Alphonsus, C., Akpa, G. N., Oni, O. O., Rekwot, P. I., Barje, P. P. and Yashim, S. M., 2010. Relationship of linear conformation traits with body weight, body condition score and milk yield in Friesian $\times$ Bunaji cows, Journal of Applied Animal Research, issue 38(1), pp. 97-100. https://doi.org/10.1080/09712119.2010.9707164 
15. Bilal, G., Cue, R. I. and Hayes, J. F., 2016. Genetic and phenotypic associations of type traits and body condition score with dry matter intake, milk yield, and number of breedings in first lactation. Can. J. Anim. Sci., issue 96, pp.434-447. doi:org/10.1139/cjas-2015-0127.

16. De Haas, Y., Janss, L. L. G. and Kadarmideen, H. N., 2007. Genetic and phenotypic parameters for conformation and yield traits in three Swiss dairy cattle breeds. J. Anim. Breed. Genet., issue 124(1), pp. 12-19. DOI:10.1111/j.14390388.2007.00630.x

17. Efimova, L. V., Rostovtseva, N. M., Kulakova, T. V., Ivanova, O. V. and Ivanov, E. A., 2017. Russian Journal of Agricultural and Biological Sciences, no. 2, pp.4-15.

18. ICAR Guidelines for conformation recording of dairy cattle, beef cattle and dairy goats, 1/76. Section 5 , Conformation Recording, version June, 2018. [Електронний ресурc]. Rezhim dostupu: https://www.icar.org/Guidelines/05-ConformationRecording. pdf

19. Tapki, I. and Ziya, G. Y., 2013. Genetic and phenotypic correlations between linear type traits and milk production yields of Turkish Holstein dairy cows. Green. J. Agric. Sci., issue 3(11), pp. 755-761.

20. Zink, V., Zavadilová, L., Lassen, J., Štípková, M., Vacek, M. and Štolc, L., 2014. Analyses of genetic relationships between linear type traits, fat-to-protein ratio, milk production traits, and somatic cell count in first-parity Czech Holstein cows. Czech $\mathrm{J}$. Anim. Sci., issue 59(12), pp. 539-547.

Samokhina Evgeniya Anatoliyivna, Ph.D. of Agricultural Sciences, docent

Avramenko Liliia Petrivna, Master's student of the Faculty of Biology and Technology

Chubar Alina Volodymyrivna, Master's student of the Faculty of Biology and Technology

Kuzmenko Oleksandr Mykhailovych, Master's student of the Faculty of Biology and Technology

Sumy National Agrarian University (Sumy, Ukraine) tion methods

Estimation conformation cow's of Ukrainian Black-and-White dairy breeds in Sumy region by using linear classifica-

The research of the first-born cows of Ukrainian Black-and-White dairy breed on the conformation in the herds of Sumy region (AF "Pershe Travnya" and "State Enterprise of Research Institute of Agriculture of the North-East of NAAS of Ukraine"). The animals were evaluated according to the method of linear classification at 2-4 months after calving. The 9-score system described 18 traits of the conformation. Four groups of conformation traits, which characterize the dairy type, body, limbs and udder, were estimated on a 100-score scale. The estimate for group traits that characterize the dairy type was (82.4 and 81.4 score, respectively), body (83.5 and 82.4 score), limbs (82.6 and 81.7 score), udder (81.9 and 80.7 score) and the overall score by type (82.5 and 81.5 score) with the highest rates in cows of the herd AF "Pershe Travnya". Assessment of descriptive traits of first-born cows showed that the degree of their development, compared with group, has a significantly higher variability both inside the herd and between herds with coefficients of variation 11.9-37.3\%. In both experimental farms, was established a sufficient for effective selection connection level of milk yield amount between group traits of the conformation that characterize the severity of dairy type of cows ( $r=$ 0.338 and 0.279), body development ( $r=0.422$ and 0.344), udder quality ( $r=0.315$ and 0.299$)$ and overall type assessment ( $r=$ 0.328 and 0.277 ). A positive relationship with milk yield was observed for a number of individual descriptive traits of the conformation similarly within the controlled farms: rump height ( $r=0.355$ and 0.266), body depth ( $r=0.326$ and 0.333$)$, angularity ( $r=0.355$ and 0.328), rump width ( $r=0.398$ and 0.341), pelvic limbs posture $(r=0.402$ and 0.304$)$, fore $(r=0.312$ and 0.267$)$ and rear udder attachment $(r=0.151$ and 0.145$)$, central ligament $(r=0.237)$ and 0.263$)$, locomotion $(r=0.253$ and 0.227$)$. The correlation between body condition and milk yield was negative $(r=-0.222$ and -0.188$)$. The use of linear classification methods in the selection process of dairy cattle allowed determining the breed features of the conformation of animals, and a significant correlation between linear traits and milk yield confirmed the need for indirect selection by type, which will improve both the conformation and dairy productivity.

Key words: Ukrainian Black-and-White dairy breed, conformation, milk yield, linear type estimation, correlation

Дата надходження до редакції: 08.02.2021 p. 